\title{
Serological identity between human alpha uterine protein and human progestagen-dependent endometrial protein
}

\author{
R. G. Sutcliffe, S. G. Joshi*, W. F. Paterson and J. F. Bank* \\ Institute of Genetics, University of Glasgow, Church Street, Glasgow G11 SJS, U.K. and \\ *Department of Obstetrics and Gynaecology, The Neil Hellman Medical Research Building, \\ Albany Medical College, Albany, New York 12208, U.S.A.
}

\begin{abstract}
Summary. Alpha uterine protein and progestagen-dependent endometrial protein were previously described in human endometrium by two independent groups of workers. Serological evidence is presented in this paper that these two proteins are the same.
\end{abstract}

\section{Introduction}

Human endometrial proteins have attracted interest because the uterus is a hormonal target organ which permits and supports the implantation of the embryo (see Aitken, 1979). A protein, called alpha uterine protein (AUP) was reported to be present in the endometrium of pregnant women and in amniotic fluid (Sutcliffe, 1976; Sutcliffe, Brock, Nicholson \& Dunn, 1978) and detectable in non-pregnant endometrium and placenta (Sutcliffe et al., 1978). The protein had an estimated molecular weight of 50000 due to two subunits of 23000-25000 molecular weight (Sutcliffe, Bolton, Sharp, Nicholson \& MacKinnon, 1980). In 1976, Joshi (1977) presented evidence for the preferential synthesis of an antigenic protein in the human decidua of pregnancy. The protein was termed progestagen-dependent endometrial protein (PEP) and was detected in pregnancy in the decidua and amniotic fluid and the secretory-phase endometrium of cyclic women (Joshi, Ebert \& Swartz 1980a; Joshi, Smith \& Stokes, 1980c). There was found to be a direct relationship between endometrial concentration of the protein and the serum progesterone levels (Joshi, Henriques, Smith \& Szarowski 1980d). The molecular weight and subunit size of PEP are similar to those of AUP and both are glycoproteins since they bind concanavalin-A (Joshi, Ebert \& Smith, 1980b; Paterson, 1981).

In view of the similarities between AUP and PEP an exchange of antisera and antigens was made between the Glasgow and the Albany groups for comparative tests.

\section{Materials and Methods}

The sources of antigen for the tests were (a) a decidual glycoprotein fraction from Albany, New York (Joshi et al., 1980a) and (b) aliquots from a large pool of second trimester human amniotic fluid from Glasgow. The rabbit antisera against AUP and PEP have been previously described (Sutcliffe, 1976; Joshi, 1977; Sutcliffe et al., 1978). Double immunodiffusion was carried out as described by Ouchterlony \& Nilsson (1978) and the precipitin lines were stained with Coomassie Brilliant Blue R. 


\section{Results and Discussion}

When tested by double immunodiffusion the rabbit anti-AUP and anti-PEP sera each gave a strong reaction against amniotic fluid and decidual extracts, as previously reported (see 'Introduction'). A reaction of identity was observed between the antisera to AUP and to PEP (Textfig. 1). When the antisera were mixed (Text-fig. 2) a clear reaction of identity was observed between the two antigens, involving a single precipitin reaction. The two antisera therefore react against the same antigen in the same materials. This result was obtained in both laboratories.

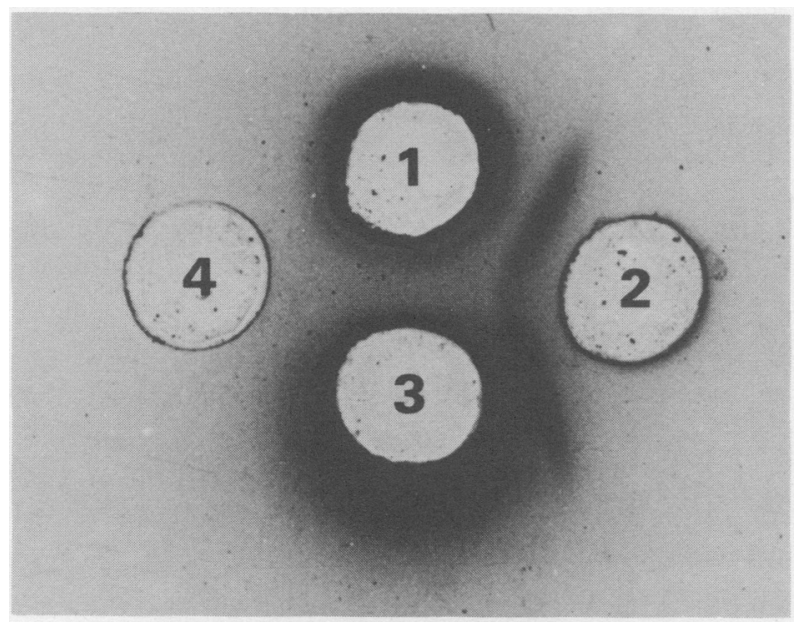

Text-fig. 1. Ouchterlony double immunodiffusion showing rabbit antisera to AUP (Well 1) and PEP (Well 3) reacting against amniotic fluid (Well 2). Each well contained $10 \mu$ samples. Well 4 contained physiological saline $(9 \mathrm{~g} \mathrm{NaCl} / 1)$.

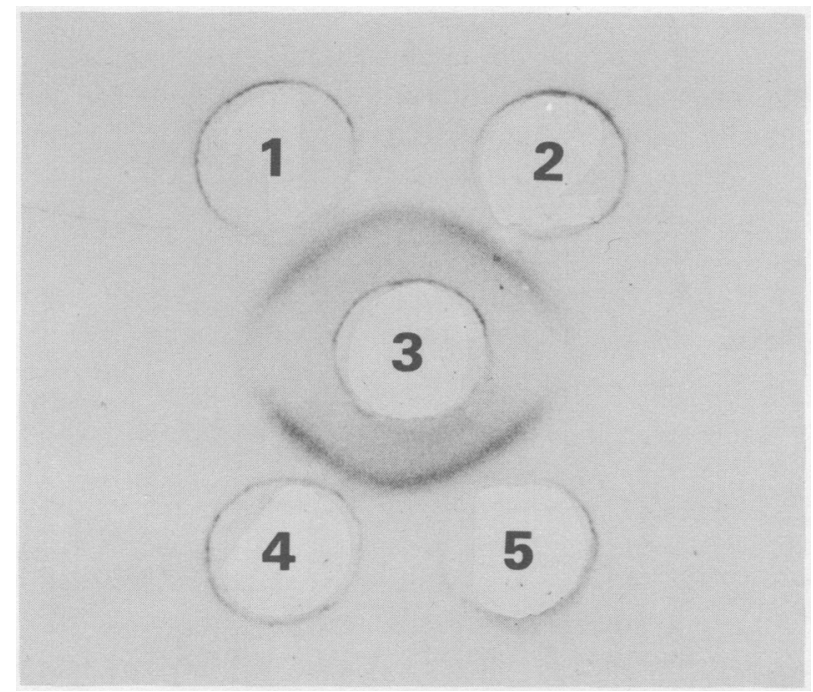

Text-fig. 2. Ouchterlony double immunodiffusion plate illustrating immunological identity of AUP and PEP. Volumes $(10 \mu \mathrm{l})$ of the following antigens and antisera were introduced into $4 \mathrm{~mm}$ diameter wells cut in $1 \%$ agarose. Wells 1 and 5: pooled human amniotic fluid, $54.8 \mu \mathrm{g}$ protein; $10 \mathrm{mU}$ (AUP); Wells 2 and 4: decidual glycoprotein fraction (source of PEP); Well 3: anti-PEP serum $(5 \mu)$ plus anti-AUP serum $(5 \mu)$. Precipitin lines were stained with $2 \%$ Coomassie Brilliant Blue. 
On the basis of this serological evidence, we conclude that AUP and PEP are the same molecule. This conclusion is strongly supported by the similarity in molecular weight, subunit size and lectin binding (see 'Introduction'). The function of this molecule is unknown. It may have an extracellular function in early pregnancy, since it is at highest concentration in amniotic fluid early in pregnancy (Sutcliffe et al., 1978; Joshi et al., 1980c). This concentration in amniotic fluid presumably reflects the high level of the protein found in endometrium early in pregnancy. It does not bind progesterone with appreciable affinity (Paterson, 1981).

This work was supported by grants from the U.K. M.R.C. (to R.G.S.) and the Ford Foundation and NIH (to S.G.J.).

\section{References}

Aitken, R.J. (1979) Uterine proteins. In Oxford Reviews of Reproductive Biology, Vol. 1, pp. 351-382. Ed. C. A. Finn. Oxford University Press, Oxford.

Joshi, S.G. (1977) In discussion (pp. 246-247) of paper entitled "Protein composition of human endometrium and its secretion at different stages of menstrual cycle" by P. M. Hirsch, L. L. Fergusson \& R. J. B. King. Ann. N.Y. Acad. Sci. 286, 233-245.

Joshi, S.G., Ebert, K.M. \& Swartz, D.P. (1980a) Detection and synthesis of a progestagen-dependent protein in human endometrium. J. Reprod. Fert. 59, 273-285.

Joshi, S.G., Ebert, K.M. \& Smith, R.A. (1980b) Properties of the progestagen-dependent protein of the human endometrium. J. Reprod. Fert. 59, 287-296.

Joshi, S.G., Smith, R.A. \& Stokes, D.K. (1980c) A progestagen-dependent endometrial protein in human amniotic fluid. J. Reprod. Fert. 60, 317-321.

Joshi, S.G., Henriques, E.S., Smith, R.A. \& Szarowski,
D.H. (1980d) Progestagen-dependent endometrial protein in women: Tissue concentration in relation to developmental stage and to serum hormone levels. Am. J. Obstet. Gynec. 138, 1131-1136.

Ouchterlony, O. \& Nilsson, L.A. (1978) Immunodiffusion and immunoelectrophoresis. In Handbook of Experimental Immunology, 3rd edn., ch. 19, pp. 19.1-19.44. Ed. D. M. Weir. Blackwell, Oxford.

Patterson, W.F. (1981) Studies on human uterine protein. M.Sc. thesis, University of Glasgow.

Sutcliffe, R.G. (1976) The search for new human fetal proteins. Protides Biol. Fluids 24, 543-546.

Sutcliffe, R.G., Brock, D.J.H., Nicholson, L.V.B. \& Dunn, E. (1978) Fetal- and uterine-specific antigens in human amniotic fluid. J. Reprod. Fert. 54, 85-90.

Sutcliffe, R.G., Bolton, A.E., Sharp, F., Nicholson, L.V.B. \& Mackinnon, R. (1980) Purification of human alpha uterine protein. J. Reprod. Fert. 58, 435-442.

Received 6 August 1981 